\title{
Identification of Scouring Zones in Ungauged River by Simulation: The Case of Galal Badrah River, Iraq
}

\author{
Kareem Abd Ali Kareem ${ }^{1, *}$, and Hayder A.K. AL-Thamiry ${ }^{2}$ \\ ${ }^{1}$ Department of Water resources, University of Baghdad, Baghdad, Iraq, kareemalialagha@gmail.com \\ ${ }^{2}$ Department of Water resources, University of Baghdad, Baghdad, Iraq, hy_hyder@coeng.uobaghdad.edu.iq \\ * Corresponding Author: Kareem Abd Ali Kareem kareemalialagha@gmail.com \\ Published online: 31 August 2019
}

Abstract- Galal Badrah River is one of Iraqi-Iranian border crossing rivers. This river is usually seasonally flooded during any time started from January to May. Its maximum discharge is $2200 \mathrm{~m} 3 / \mathrm{s}$ which was recorded during 1985. During floods, banks of this river at many locations need protection against scour problem during floods. A small dam was constructed on this river in 2010 for the purposes of flood control and storage of water. The weir of the dam has a design discharge of $1250 \mathrm{~m} 3 / \mathrm{s}$. Sediments started to accumulate in the reservoir of the dam that reduce its design capacity to $10 \%$ during 2017 . The flow of Galal Badrah River was simulated by using HEC-RAS 5.0.3 models. were used to simulate by using. Two hydrographs were used at upstream side of the river, one with a maximum discharge of $1250 \mathrm{~m} 3 / \mathrm{s}$ and the other is of $2200 \mathrm{~m} 3 / \mathrm{s}$. A normal flow depth is used as a downstream boundary condition. Results of the simulation showed that the velocities to be higher than allowable velocity of scouring. The protection of Galal Badrah river by stack boulders is suggested to be used to avoid the scour at the river bank. The protection will increase Manning's roughness coefficient from 0.028 to 0.10 . The percentage of reduction in velocities after the river protection for the discharges of 1250 and $2200 \mathrm{~m} 3 / \mathrm{s}$ were found to be $65.23 \%$ and $60.55 \%$, respectively. The reduction in velocity caused increase in the river water levels. As a result, a flood embankment is required to be constructed on the right bank of the river with a height ranges from 2.5 to $5.6 \mathrm{~m}$ depending on the water depth at river cross section.

Keywords- Galal Badrah River, Two Dimensional simulation, flood, bank protection.

\section{Introduction}

Scour is a natural phenomenon caused by the erosive action of flowing water on the bed and banks of alluvial channels. Scour and deposition are the main problems in many rivers in Iraq especially in the seasonal rivers. Galal Badrah River is a seasonal border crossing river and most of its catchment area lies within the Iranian borders. Iraqi Government constructed a small dam on the Galal Badrah River. This dam is used to reduce the risk of flood and for storage purposes. The dam is located near the Iraq-Iran Boarder. Recently, the reservoir of the dam is filled with sedimentation. Sediment accumulation makes the reservoir not functional and the probability of river flooding increases. Improper operation of bottom gate of the weir during 2013 leads to more sediment accumulation. Accumulation of sediments behind the weir cannot be controlled during the flood. Until the maintenance of the reservoir, a study is needed to consider the protections along the river at high discharges. This study aimed at studying the locations of flow velocity that cause scour in the riverbanks.

\section{Description of Galal Badrah River}

Galal Badrah River is one of crossing rivers and its total length is $128 \mathrm{~km}$ of which $42 \mathrm{~km}$ is within the Iraqi borders. Its catchment area is about $2430 \mathrm{~km} 2$ that is mostly lie within the Iranian borders. The main runoff accrues during January to May every year. the maximum recorded discharge of $2200 \mathrm{~m} 3 / \mathrm{s}$ was recorded during 1985. This discharge caused maximum scour in the river banks and bed at different locations. A small dam was constructed during 2010 on the Galal Badrah River. This dam is used for flood protection and to store the seasonal incoming discharges. The dam is located at just $16 \mathrm{~km}$ from the Iraq-Iran Boarder. The design discharge of the weir of the dam is $1250 \mathrm{~m} 3 / \mathrm{s}$. 
The capacity of the dam is reduced greatly due to the accumulation of sediments within its reservoir. Accumulation of sediments behind the weir cannot be controlled during the flood.

\section{Objectives of study}

In this research, a one-dimensional mathematical model is used to simulate the locations of critical scour velocities and a two dimensional mathematical model is applied to simulate the flood wave from the location of Galal Badrah weir until Badrah City. Accordingly, the two models will predict the velocity pattern, water depth and water levels along the river reach that will be used to identify the locations of scour along the river that need suitable protection.

\section{Methodology}

The methodology of the present work can be summarized by the following steps:

1- Collection of available hydrological and bathometric data on the study area.

2- Collection of soil samples from the river bed and banks at selected locations.
3- Implementation of one and two-dimensional hydraulic models to investigate the velocity pattern, water depth and water level within the river and specify the factors that causes scour in the river.

4- Visit to the predicted locations with bank and bed scour that were identified by the models as locations with high velocity and this check was used in this study as model validation.

5- Prepare the possible required treatments at the areas of scouring banks, river reach to control the scour and improve the river capacity during flood.

6- Protection of scoured bed and banks of Galal River by using stack boulders.

\section{Fieldwork}

The field work was started in December 2016 and finished in March 2017. The work includes the survey of 100 cross sections of the river by using benchmark positions. Important spatial information on scour locations, longitudinal slope, and the required water levels were provided from Water Resource Division, Badrah, Wasit Governorate Then the locations of eroded banks by high flow velocities during flood were specified and soil samples were taken from these locations as shown Fig. 1 and Fig. 2.

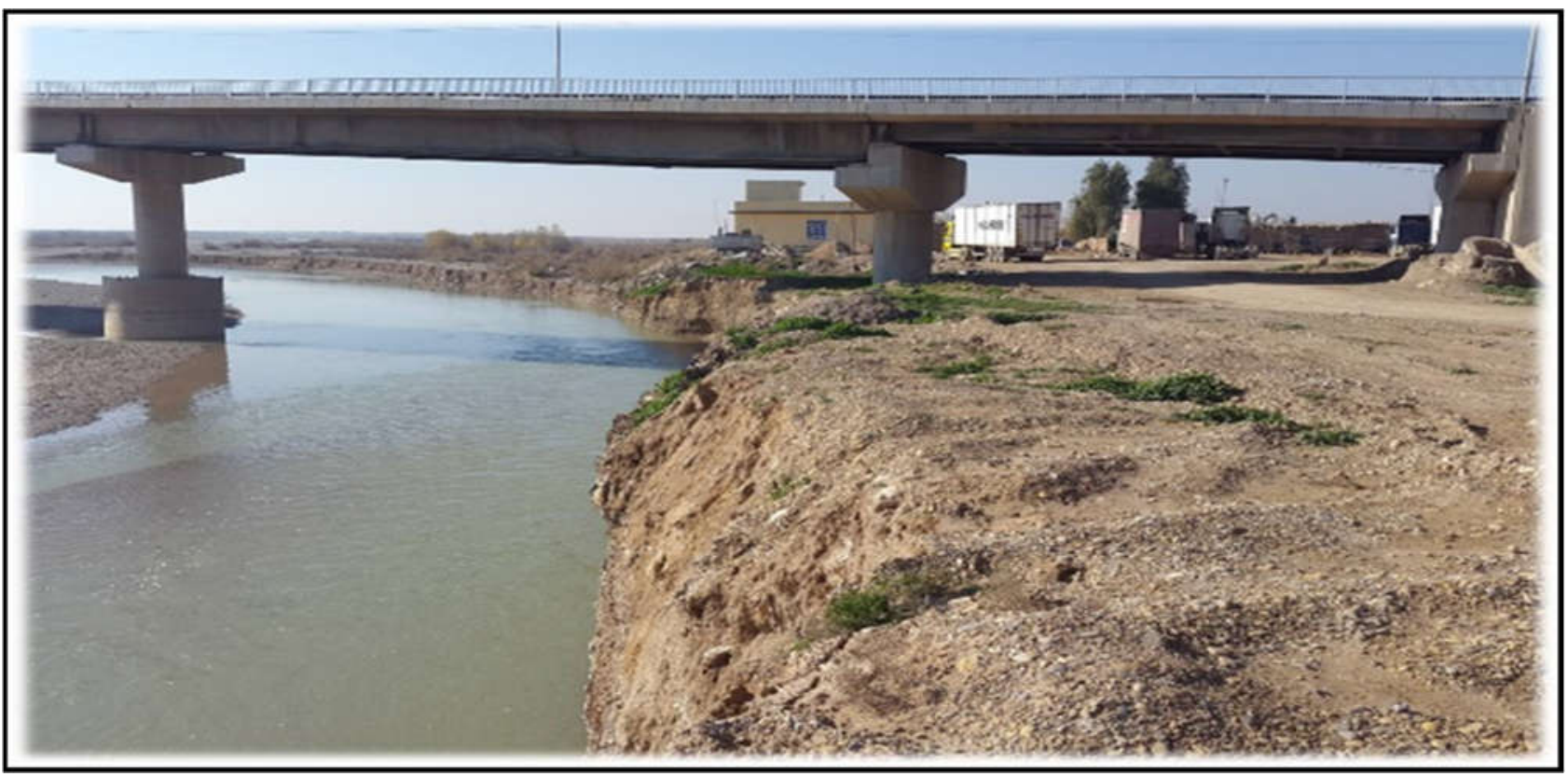

Figure 1: Banks eroded of Galal Badrah River near cross section 70. 


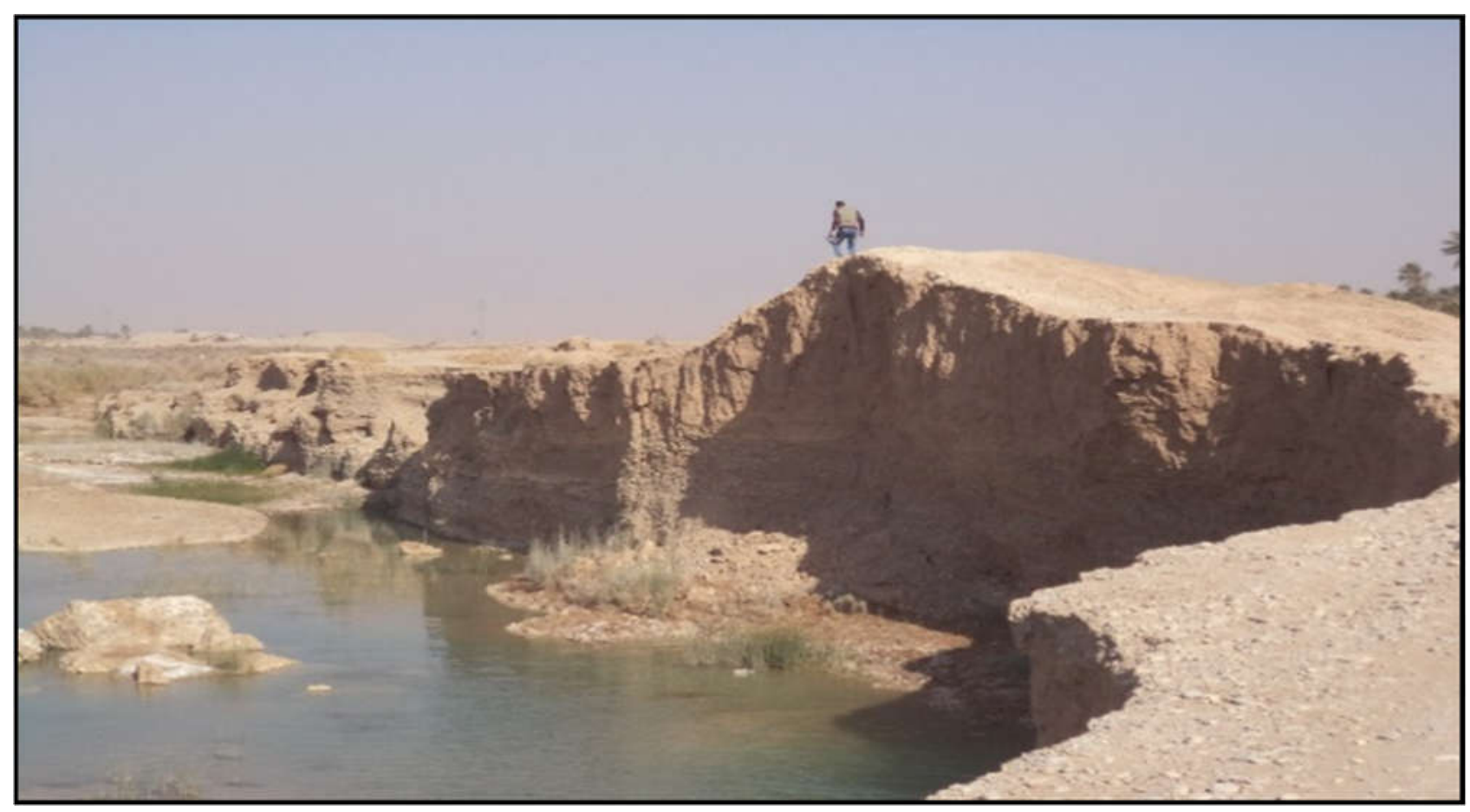

Figure 2: Banks eroded of Galal Badrah River near cross section 49.

Additionally, the investigation includes specifying the locations and information of existing hydraulic. The eroded areas along the bank of Galal Badrah River were recorded and measured. The number of scoured locations along the river banks was found to be ten locations. These locations were located by using GPS device in order to be use in the GIS software as shown in Table1. Details on the positions of weir, Bridge, cross sections, site of soil sampling ( $\mathrm{p} 1$ to $\mathrm{p} 10)$ and Badrah City are shown in Fig. 3

Table 1: Soil sampling positions, types of soil and limit of scour velocity

\begin{tabular}{|c|c|c|c|c|c|}
\hline \multirow{2}{*}{$\begin{array}{l}\text { Point of } \\
\text { scour }\end{array}$} & \multicolumn{2}{|l|}{ Position of points } & \multirow{2}{*}{ Type of soil } & $\begin{array}{l}\text { Nearby } \\
\text { cross } \\
\text { section }\end{array}$ & $\begin{array}{l}\text { scour } \\
\boldsymbol{m} / \mathbf{s}(\text { Graf, 1984) }\end{array}$ \\
\cline { 2 - 5 } & Easting, $\mathbf{~ m}$ & Northing, $\mathbf{~}$ & Silty loam & 92 & 0.76 \\
\hline P1 & 588994.02 & 3665045.40 & sandy loam & 56 & 0.91 \\
\hline P2 & 589117.40 & 3665213.92 & Sandy loam & 49 & 0.91 \\
\hline P3 & 589553.74 & 3665755.59 & Silty loam & 28 & 0.76 \\
\hline P4 & 591897.60 & 3666879.33 & Sandy loam & 11 & 0.91 \\
\hline P5 & 592416.33 & 3667014.46 & Sandy loam & 20 & 0.91 \\
\hline P6 & 592118.87 & 3667056.04 & Silty loam & 46 & 0.76 \\
\hline P7 & 589150.50 & 3666285.23 & Sandy loam & 63 & 0.91 \\
\hline P8 & 588443.31 & 3664906.97 & Sandy loam & 67 & 0.91 \\
\hline P9 & 588046.09 & 3664624.10 & Silty loam & 69 & 0.76 \\
\hline P10 & 587907.66 & 3664446.55 & & \\
\hline
\end{tabular}




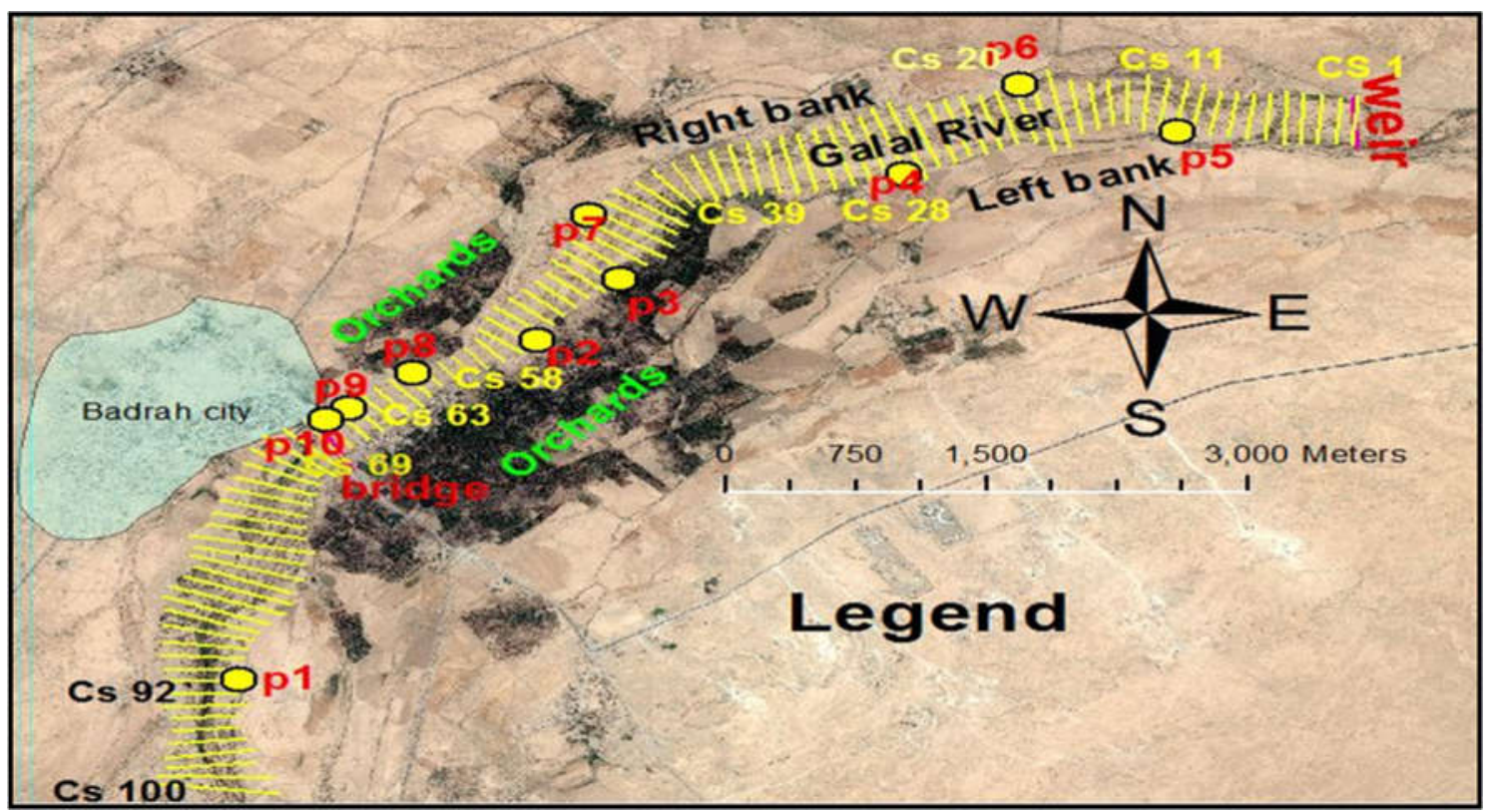

Figure 3: Main details along study area with the available cross sections and location of sampling points.

\section{Laboratory test}

Sieve and hydrometer analysis were used to determine the type of soil that form the river bed and banks. The triangular classification is used to determine the limits of scour velocity [3]. Velocity affects in soil granules by the forces of bed load and lift force of erosion. Also, the allowable velocities before erosion soil particles with soil samples Results a two types of sandy loam and silty loam. The scour velocity limit for each type of soil is $0.91 \mathrm{~m} / \mathrm{s}$ for sandy loam and $0.76 \mathrm{~m} / \mathrm{s}$ for silty loam.

\section{Application of HEC-RAS}

HEC-RAS version 5 was used for numerical simulation of the flood wave [5]. This software is based on Saint Venant equations or the two dimensional diffusion wave equations .[2] A river bank length of $10 \mathrm{~km}$ was divided into four parts and these zones are part one, part two, part three and part four and the length of these parts are 3.8, $1.9,1.3$ and $3.0 \mathrm{~km}$ respectively according to the existence of the important installations as well as to clarify more of the existing features by enlarging the longitudinal section. This process makes it essay to explain better and find the most critical and most drifting area . Two discharges for the river were considered, 1250 and $2200 \mathrm{~m} 3 / \mathrm{s}$ and a suggested hydrographs for the two discharges as an upstream boundary conditions as shown in Figures. 4 and 5 , respectively.

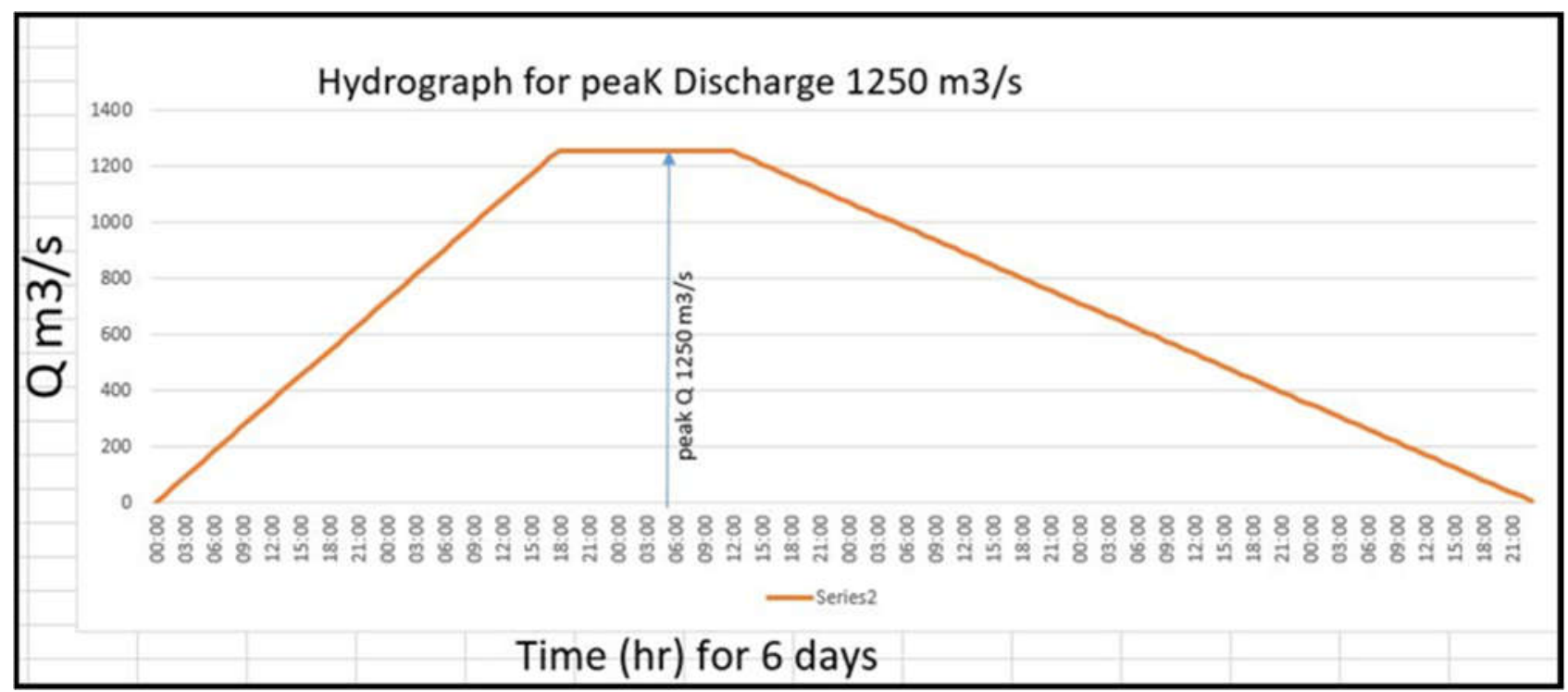

Figure 4: Suggested hydrograph with peak discharge of $1250 \mathrm{~m} 3 / \mathrm{s}$ 


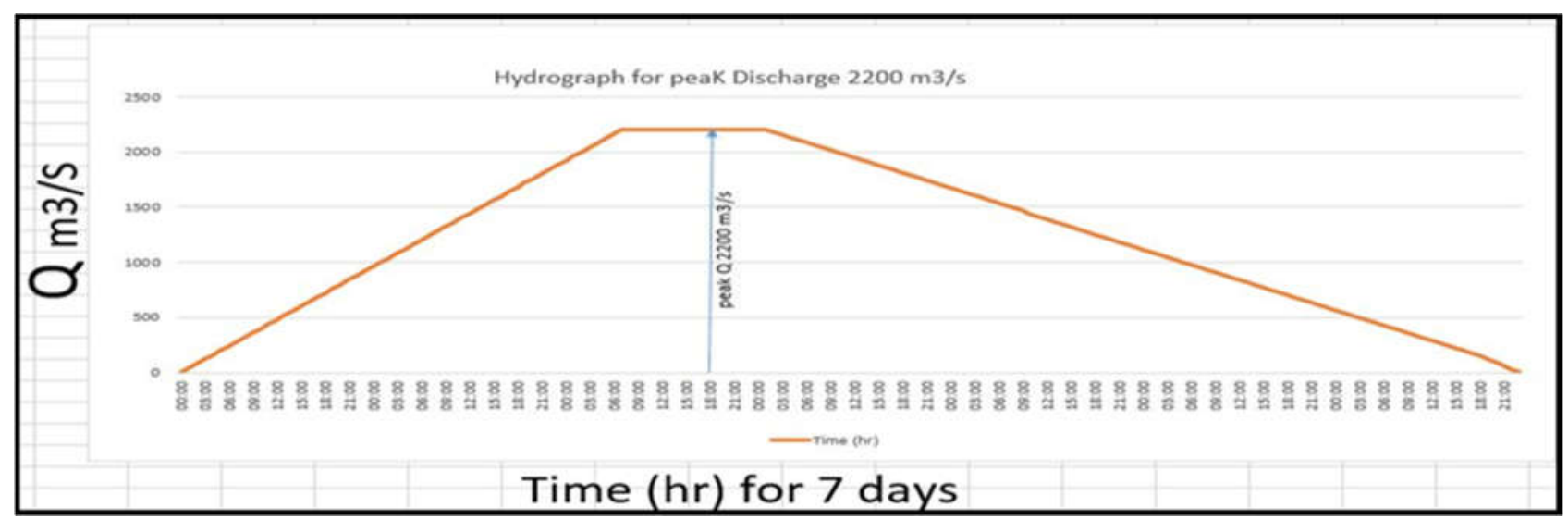

Figure 5: Suggested hydrograph with peak discharge of $2200 \mathrm{~m} 3 / \mathrm{s}$.

The downstream boundary condition is normal flow under a slope of 0.0047 . The value of Manning coefficient of roughness used before treatment for Galal Badrah River is 0.028 . The value of Manning coefficient of roughness was estimated based on the value given by Chow [1]. Terrain sketch of Galal basin by GIS software meshing (for all area mesh size $5 \mathrm{~m} * 5 \mathrm{~m}$ ), computation interval (5 sec), and hydrograph output interval (1hr). These boundary conditions and parameters were used in both cases, before and after treatment of the riverbanks.

\section{Results analysis before Protection}

For a discharge of $2200 \mathrm{~m} 3 / \mathrm{s}$, the locations of critical velocities simulated by using $2 \mathrm{D}$ model (HEC-RAS) were identified. The actual velocity pattern and longitudinal water surface profile obtained from 1D model for the river before protection are shown in Figs. 6 and 7, respectively. While, the the results for a discharge of $1250 \mathrm{~m} 3 / \mathrm{s}$ are summarized in Table 2.

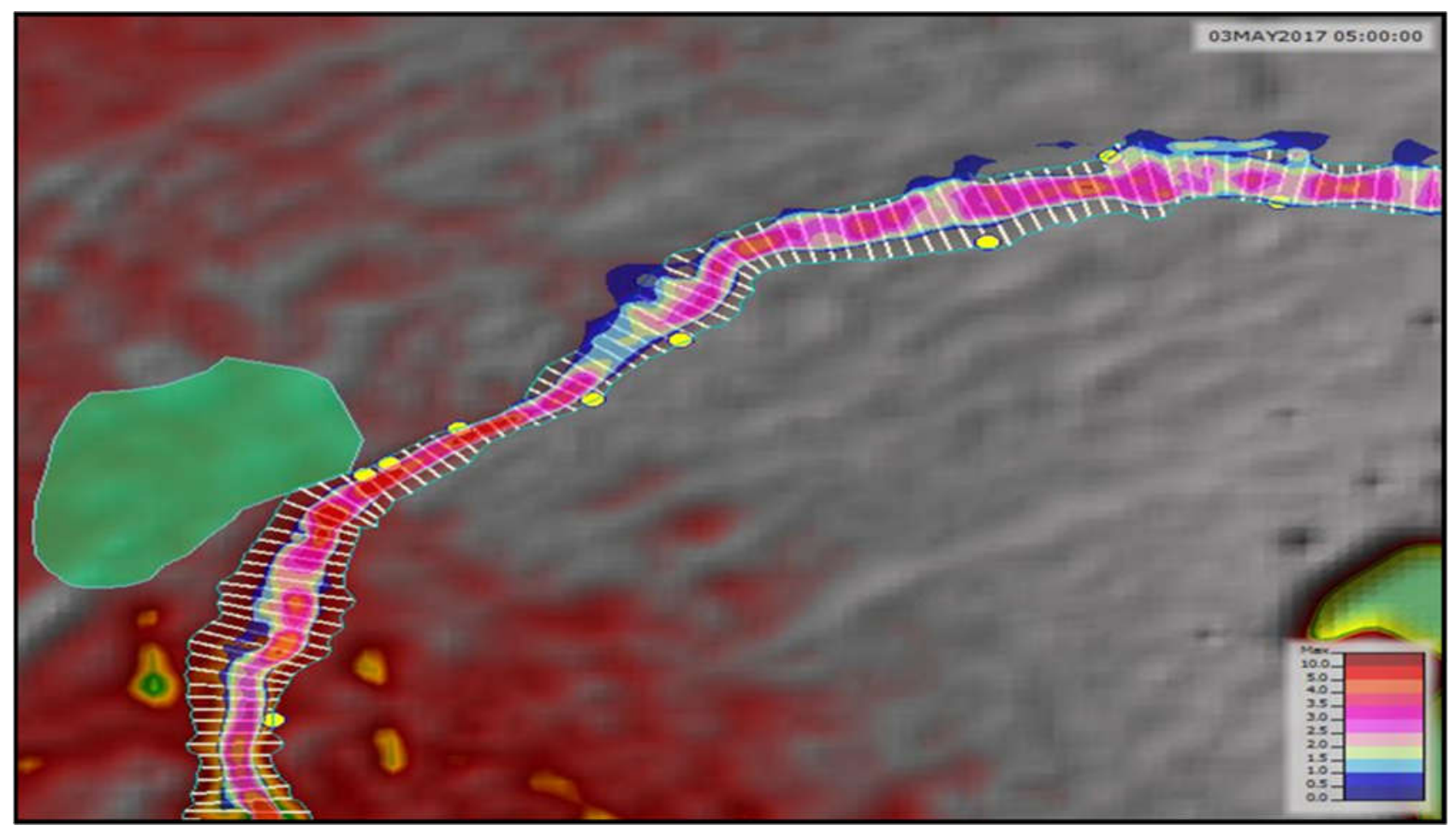

Figure 6: velocity distribution $(\mathrm{m} / \mathrm{s})$ before treatment for all zones with discharge of $1250 \mathrm{~m} 3 / \mathrm{s}$. 


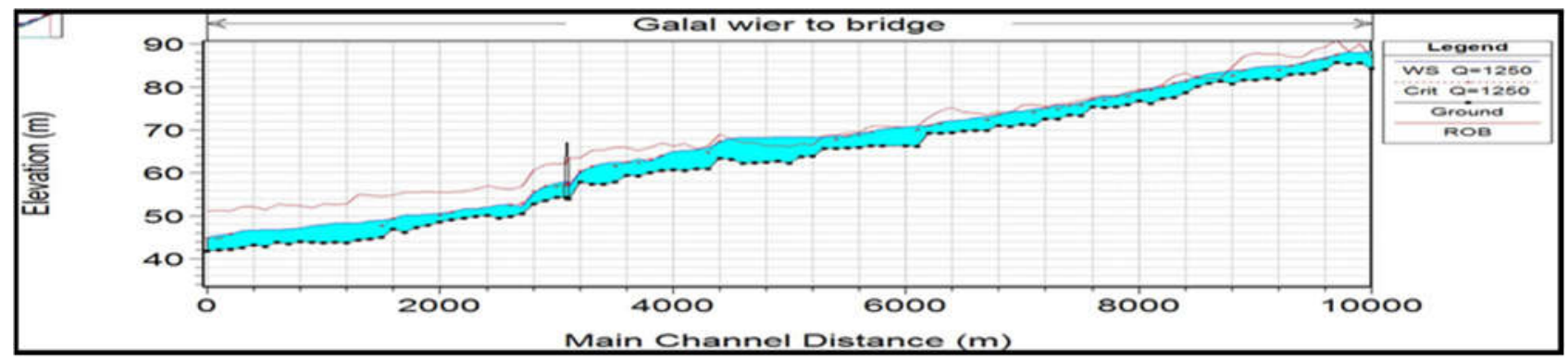

Figure 7: Actual longitudinal water surface profile for all zones with discharge of $1250 \mathrm{~m} 3 / \mathrm{s}$.

Table 2: Ranges of velocity, water depth and water surface elevation at discharge of $1250 \mathrm{~m} 3 / \mathrm{s}$.

\begin{tabular}{|c|c|c|c|c|c|}
\hline \multirow{2}{*}{$\begin{array}{c}\text { Zone } \\
\text { number }\end{array}$} & Extend of zone & Range of velocity & Range of water & \multicolumn{2}{|c|}{ Water surface elevation, m.a.s.l. } \\
\cline { 5 - 6 } &,$m$ &,$m / s$ & depth, $m$ & U/S & D/S \\
\hline 1 & $10000-6200$ & $1.50-5.10$ & $1.00-2.10$ & 87.90 & 71.70 \\
\hline 2 & $6200-4300$ & $1.25-4.50$ & $1.20-3.50$ & 71.70 & 67.60 \\
\hline 3 & $4300-3000$ & $2.00-5.20$ & $1.75-2.50$ & 67.60 & 57.85 \\
\hline 4 & $3000-0.0$ & $1.20-5.10$ & $1.20-2.10$ & 57.85 & 43.90 \\
\hline
\end{tabular}

For peak discharge of $2200 \mathrm{~m}^{3} / \mathrm{s}$, results from 1D and 2D models include ranges of velocities and water surface elevation at all parts before protection. Table 3 shows the simulated velocities and water depths. The velocity pattern and longitudinal water surface profile obtained from 1D models before protection are shown in Figs. 8 and 9, respectively.

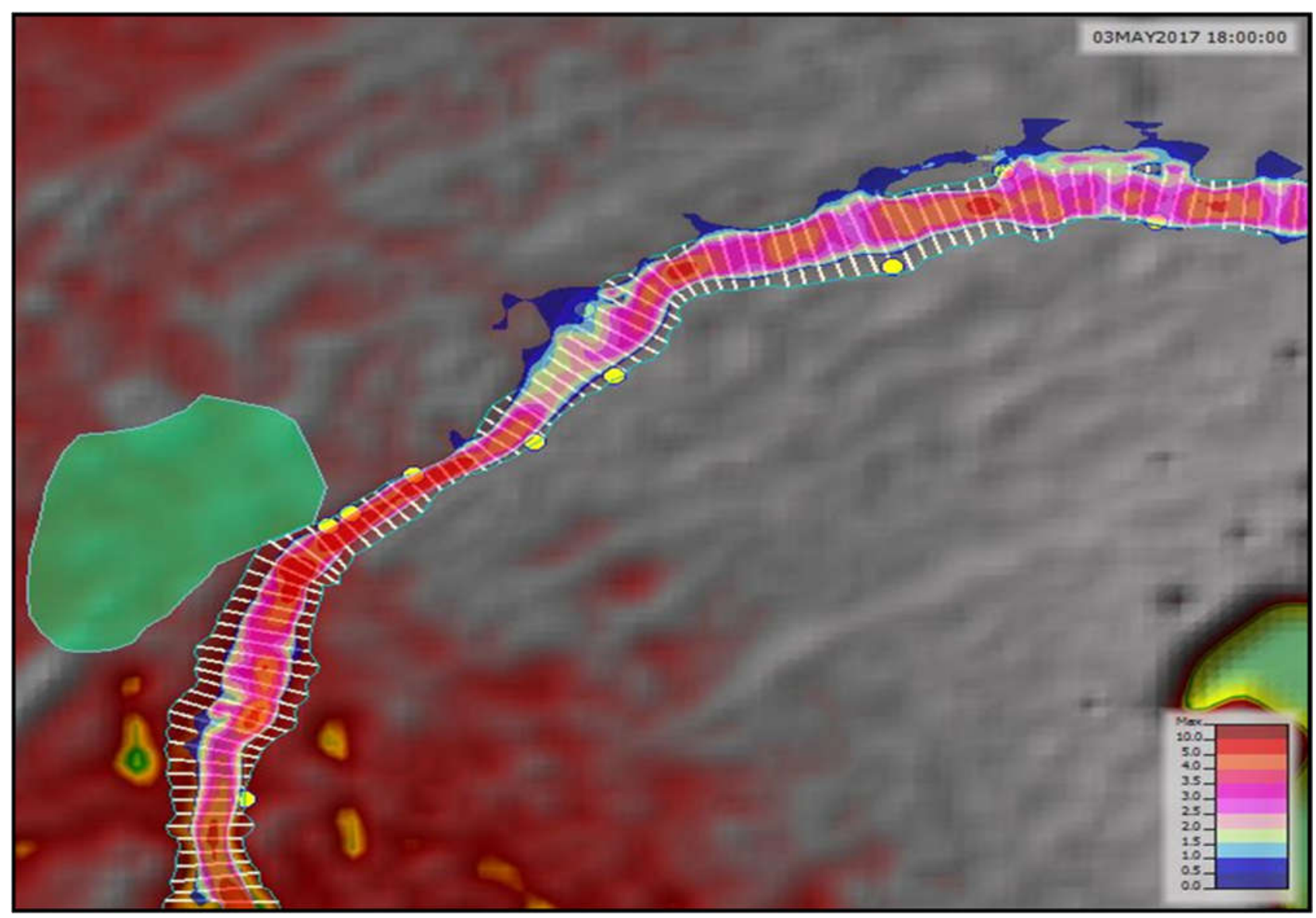

Figure 8: velocity distribution $(\mathrm{m} / \mathrm{s})$ before treatment for all zones with discharge of $2200 \mathrm{~m} 3 / \mathrm{s}$. 


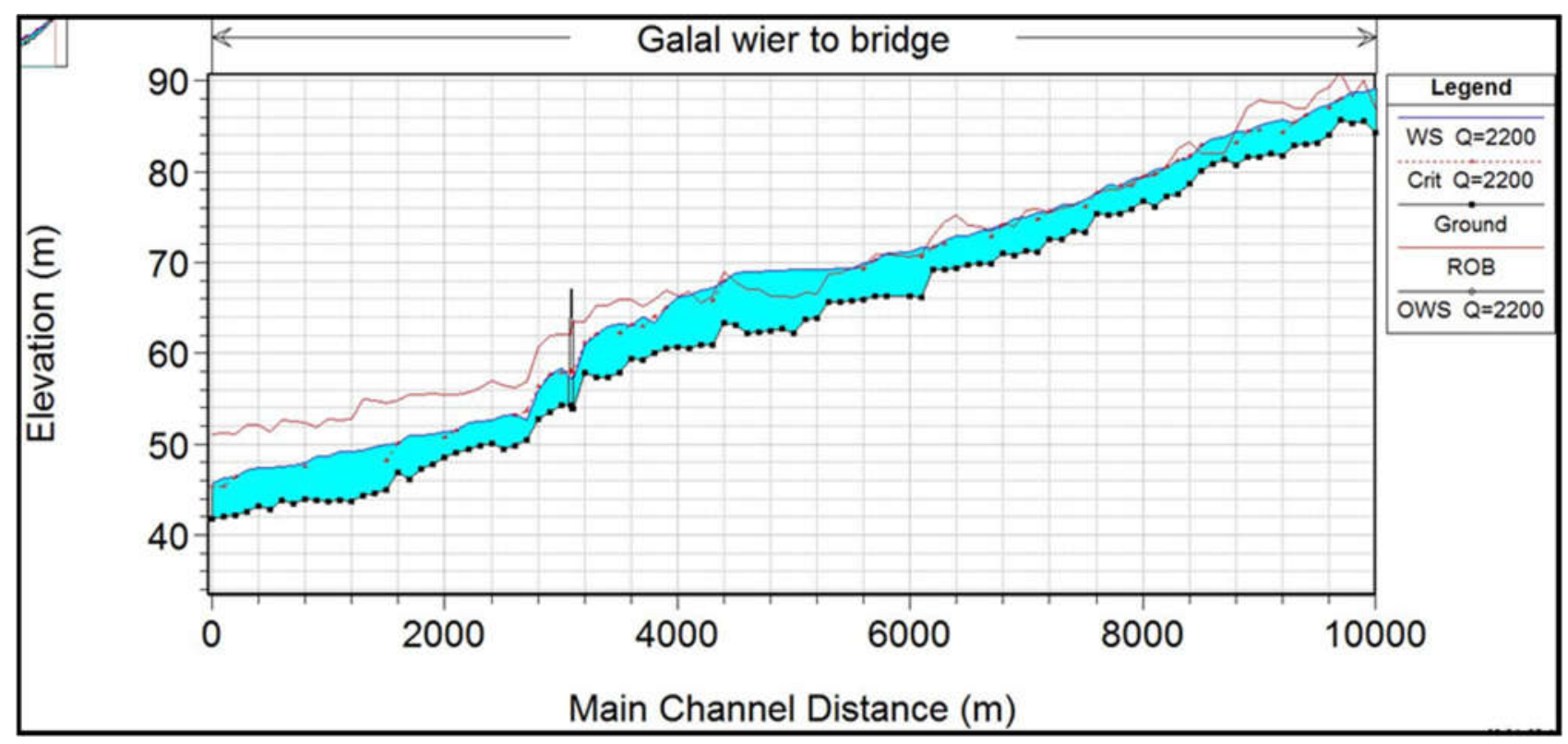

Figure 9: longitudinal water surface profile for all zones with discharge of $2200 \mathrm{~m} 3 / \mathrm{s}$.

Table 3: Ranges of velocity, water depth and water surface elevation at discharge of $1250 \mathrm{~m} 3 / \mathrm{s}$.

\begin{tabular}{|c|c|c|c|c|c|}
\hline \multirow{2}{*}{$\begin{array}{c}\text { Zone } \\
\text { number }\end{array}$} & $\begin{array}{c}\text { Extend of zone } \\
m\end{array}$ & $\begin{array}{c}\text { Range of } \\
\text { velocity }, m / s\end{array}$ & $\begin{array}{c}\text { Range of water } \\
\text { depth, } m\end{array}$ & \multicolumn{2}{|c|}{ Water surface elevation, $m . a . s . l}$. \\
\cline { 3 - 6 } & & & $1.8-3.5$ & 88.75 & 72.65 \\
\hline 1 & $10000-6200$ & $2.0-6.1$ & $2.0-4.7$ & 72.65 & 68.75 \\
\hline 2 & $6200-4300$ & $1.8-5.9$ & $2.4-3.9$ & 58.75 & 58.52 \\
\hline 3 & $4300-3000$ & $3.5-8.4$ & $2.0-3.5$ & 58.25 &
\end{tabular}

High velocity resulted from the steep longitudinal slope of Galal Basin at this part, and the actual velocities in these parts are higher than the critical velocity. Therefore the river bank at these location need protection to avoid scouring. There are many locations have supercritical flow with Froude number higher than 1 , so all locations need to protection in order to avoid scouring problem.

\section{Protections along Galal Badrah river}

River banks and bed protection works may be done by placement of riprap or other forms of protection in order to prevent erosion by flowing water [4]. Other type of erosion-resistant materials that can be placed directly on the eroded bank are gabion, riprap, cascade weirs and stack boulders. In Galal Badrah River, the protection by stack boulders was done because the material is available within the study area. The materials used can allow a velocity of $1.82 \mathrm{~m} / \mathrm{s}$ without scouring Therefore, boulders is proposed to protect the river banks and bed; the size of the boulders used is more than $256 \mathrm{~mm}$, and boulder material is used because it is available near the site. The boulder will increase the roughness coefficient at the river as reported by Chow [1] and it will increase to 0.1 . The simulation is conducted in order to determine the Manning's coefficient of roughness for the protected parts of the river. The results of all parts with different discharges of (1250 and 2200 $\mathrm{m} 3 / \mathrm{s}$ ) are presented including with the suggested protection.

\section{Result of after Bank and Bed Protection}

For all zones after protection, the simulation of velocities, water depth and longitudinal water surface profiles for a peak discharges of 1250 and $2200 \mathrm{~m} 3 / \mathrm{s}$ are shown in Figs. 10 and 11 respectively. The results for peak discharge $1250 \mathrm{~m} 3 / \mathrm{s}$ using 1D and 2D models after protection by boulder for all zones are presented in Table 4 . The comparison between 1D and 2D models, there are required fill to increase the right bank levels for all zones of Galal Badrah River at discharge of $1250 \mathrm{~m} 3 / \mathrm{s}$. In these locations a free board of $1.0 \mathrm{~m}$ height are presented in Table 5 . 


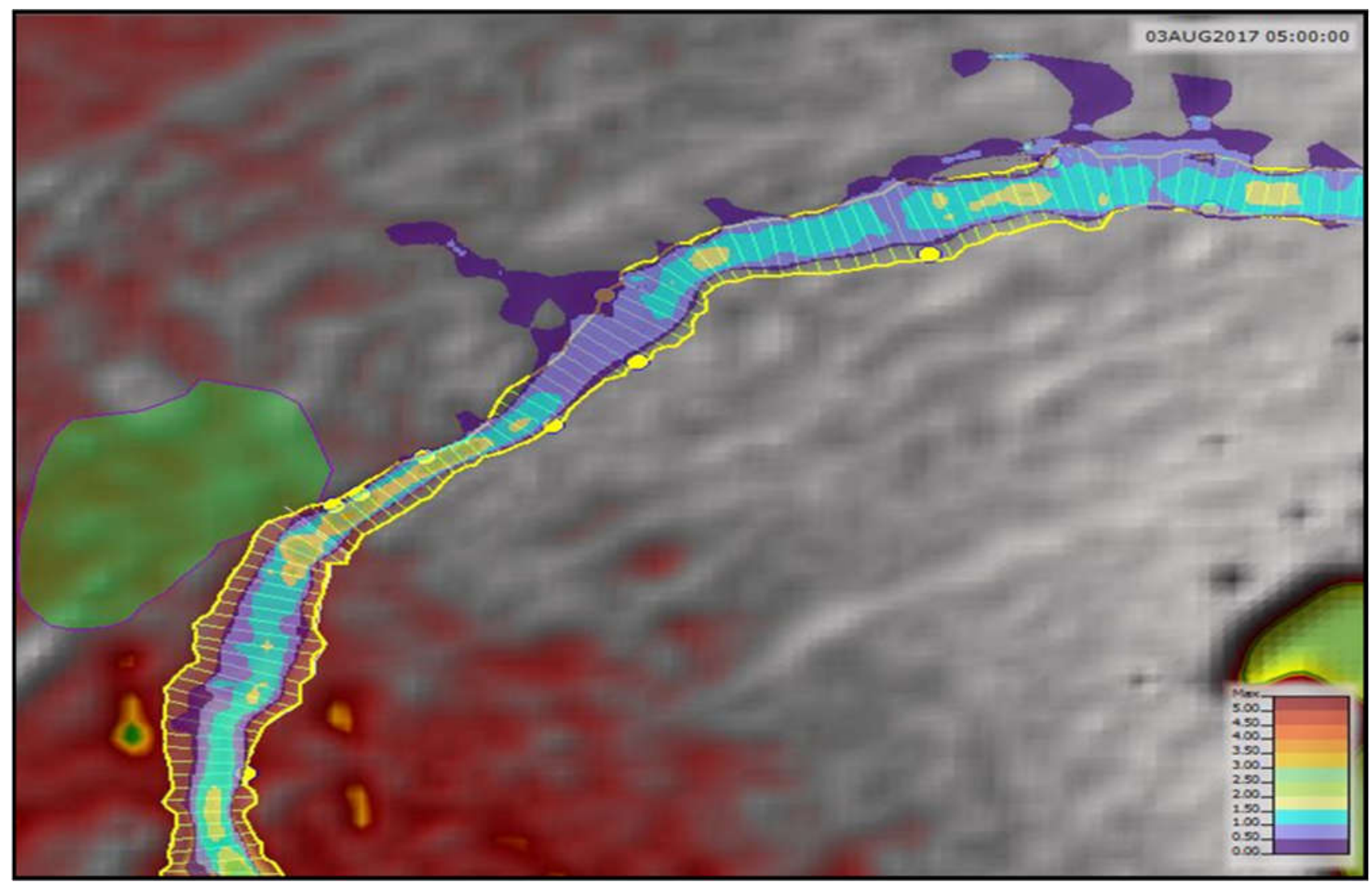

Figure 10: longitudinal water surface profile for all zones with discharge of $2200 \mathrm{~m} 3 / \mathrm{s}$.

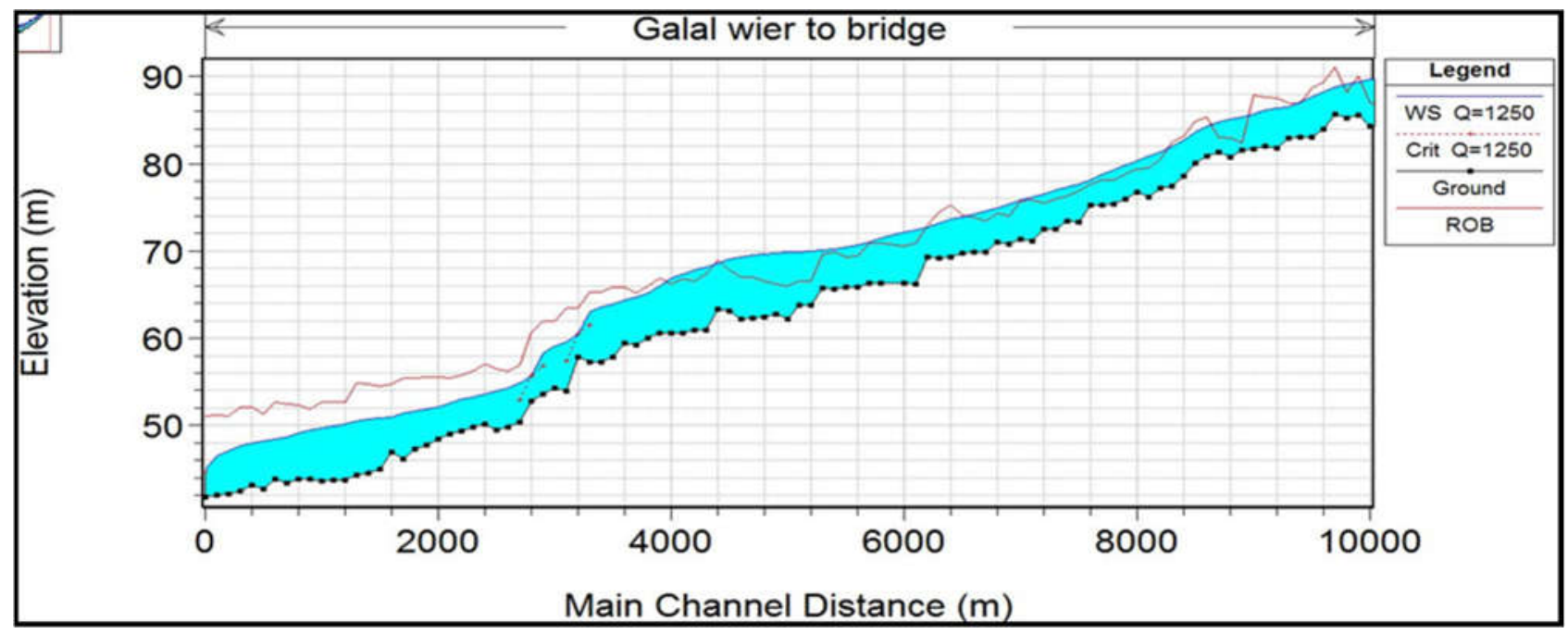

Figure 11: Longitudinal water surface profile after treatment for all zones with discharge of $1250 \mathrm{~m} 3 / \mathrm{s}$. 
Table 4: Ranges of velocity, water depth and water surface elevation of all zones after treatment at discharge of 1250 $\mathrm{m} 3 / \mathrm{s}$.

\begin{tabular}{|c|c|c|c|c|c|}
\hline \multirow{2}{*}{$\begin{array}{c}\text { Zone } \\
\text { number }\end{array}$} & \multirow{2}{*}{$\begin{array}{c}\text { Extend of zone } \\
, m\end{array}$} & \multirow{2}{*}{$\begin{array}{c}\text { Range of velocity } \\
, \mathrm{m} / \mathrm{s}\end{array}$} & \multirow{2}{*}{$\begin{array}{c}\text { Range of water } \\
\text { depth, } m\end{array}$} & \multicolumn{2}{|c|}{$\begin{array}{c}\text { Water surface elevation, } \\
\text { m.a.s.l. }\end{array}$} \\
\hline & & & & $\mathbf{U} / \mathbf{S}$ & $\mathbf{D} / \mathbf{S}$ \\
\hline 1 & $10000-6200$ & $0.40-1.50$ & $1.50-2.72$ & 88.70 & 73.25 \\
\hline 2 & $6200-4300$ & $0.32-1.40$ & $1.80-4.80$ & 73.25 & 69.20 \\
\hline 3 & $4300-3000$ & $0.55-2.60$ & $1.90-4.60$ & 69.20 & 59.10 \\
\hline 4 & $3000-0.0$ & $0.55-2.10$ & $1.80-4.50$ & 59.10 & 45.60 \\
\hline
\end{tabular}

Table 5: The required height of the right bank of Galal Badrah after treatment at discharge of $1250 \mathrm{~m} 3 / \mathrm{s}$.

\begin{tabular}{|l|l|l|l|}
\hline Stations & $\begin{array}{l}\text { Range of existing right } \\
\text { bank elevations, m.a.s.l. }\end{array}$ & $\begin{array}{l}\text { Real water surface } \\
\text { elevation, m.a.s.l. }\end{array}$ & $\begin{array}{l}\text { Required right bank level } \\
\text { m.a.s.l. }\end{array}$ \\
\hline $9850-6200$ & $87.80-72.00$ & $88.60-73.20$ & $89.60-74.20$ \\
\hline $6100-6000$ & $71.70-71.60$ & $71.97-71.83$ & $72.97-72.83$ \\
\hline $5800-4700$ & $69.10-67.50$ & $71.20-70.30$ & $72.00-71.30$ \\
\hline $4300-3500$ & $67.10-64.80$ & $70.00-65.90$ & $71.00-66.90$ \\
\hline
\end{tabular}

The simulation with a peak discharge of $2200 \mathrm{~m} 3 / \mathrm{s}$, the velocity pattern and longitudinal water surface profile are shown in Figs. 12 and 13 respectively. A Summary of 1D and 2D hydraulic models results after treatment of all zones show that the protection is successful as shown in
Table 6. The right bank of all flooded locations at discharge $2200 \mathrm{~m} 3 / \mathrm{s}$ including the required height of the right bank with free board of $1.0 \mathrm{~m}$ height are presented in Table 7.

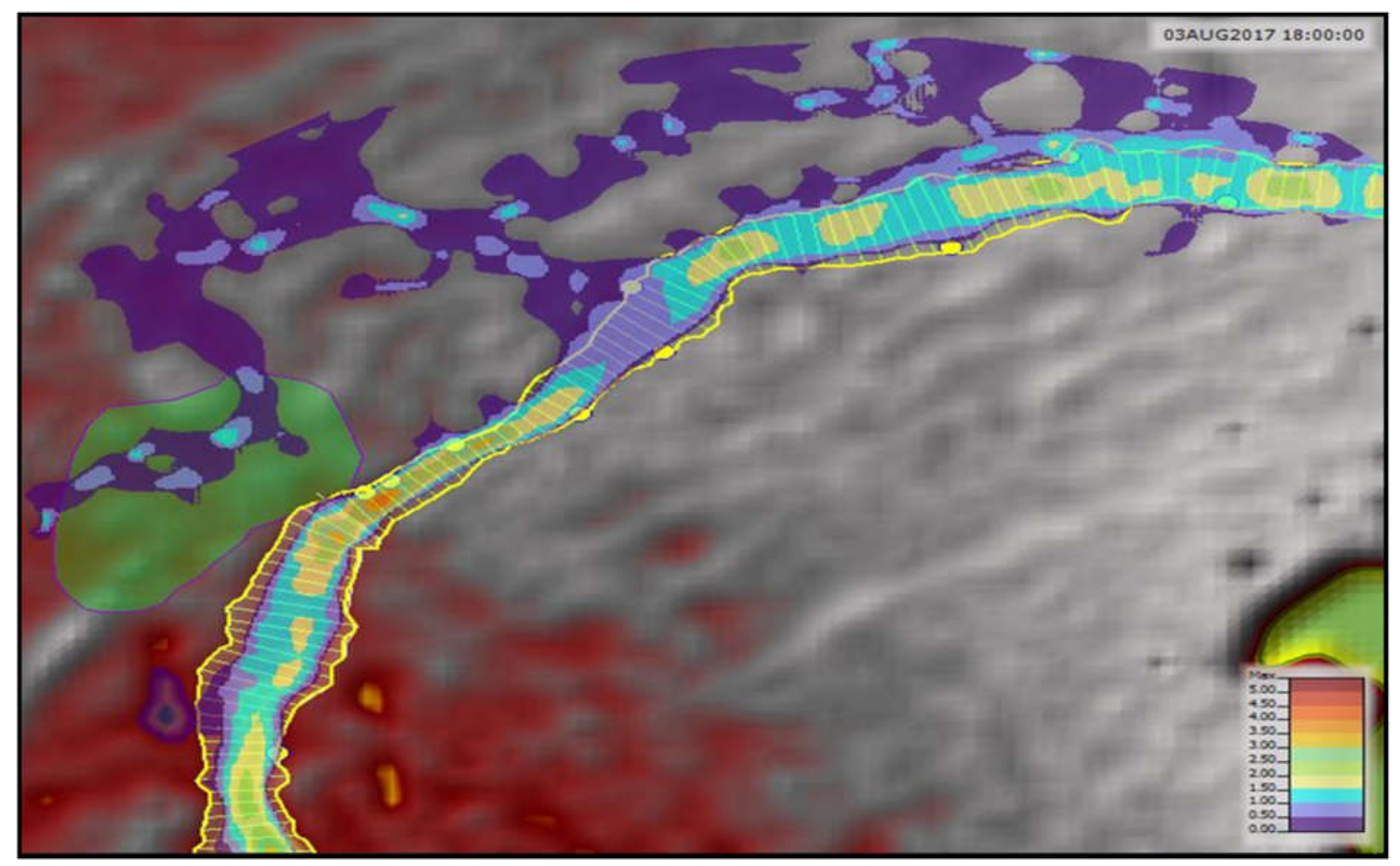

Figure 12: velocity distribution $(\mathrm{m} / \mathrm{s})$ after treatment of all zones with discharge of $2200 \mathrm{~m} 3 / \mathrm{s}$. 


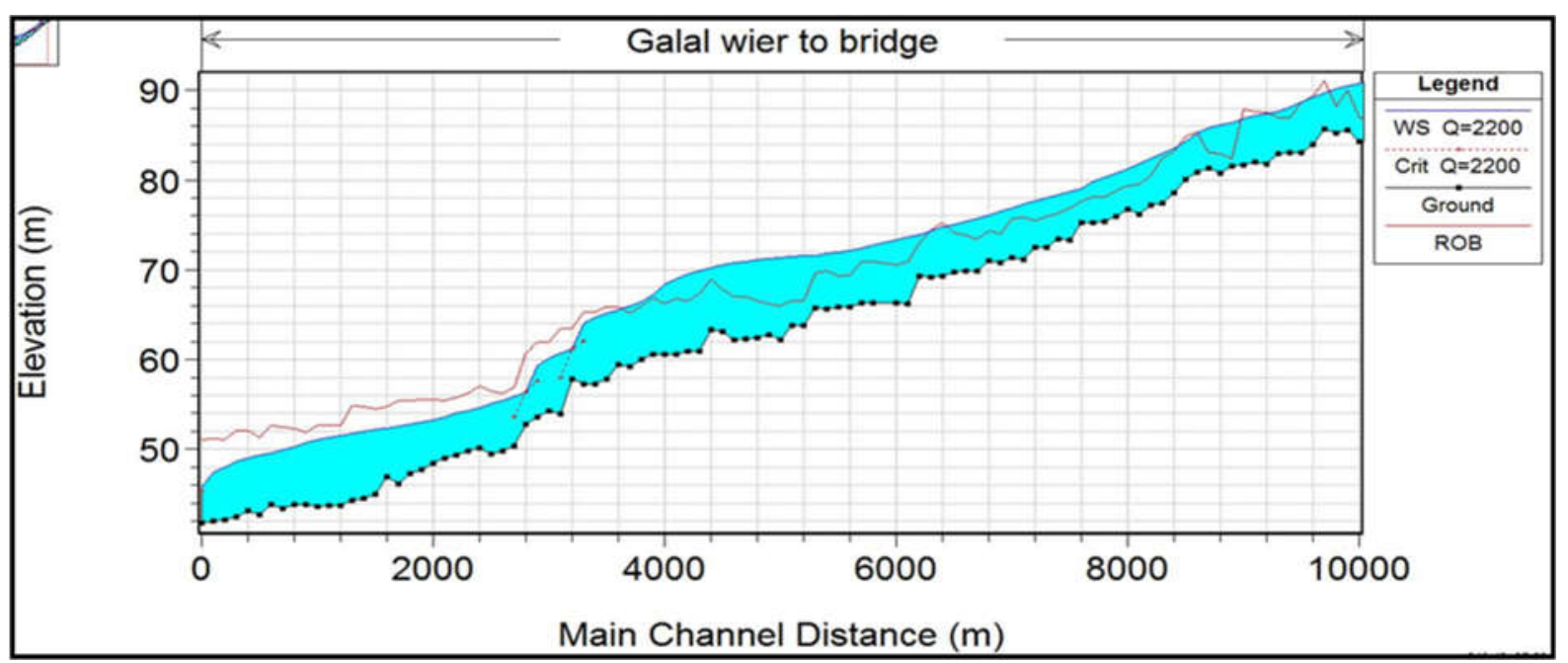

Figure 13: longitudinal water surface profile after treatment for all zones with discharge of $2200 \mathrm{~m} 3 / \mathrm{s}$.

Table 6: Ranges of velocity, water depth and water surface elevation after treatment of all zones with discharge of 2200 $\mathrm{m} 3 / \mathrm{s}$.

\begin{tabular}{|l|l|l|l|l|l|}
\hline \multirow{2}{*}{$\begin{array}{l}\text { Zone } \\
\text { number }\end{array}$} & \multirow{2}{*}{$\begin{array}{l}\text { Extend of zone } \\
m\end{array}$} & $\begin{array}{l}\text { Range of } \\
\text { velocity }, m / s\end{array}$ & $\begin{array}{l}\text { Range of } \\
\text { water depth, } \\
m\end{array}$ & & Water surface elevation, m.a.s.l. \\
\hline 1 & $10000-6200$ & $0.75-2.5$ & $2.5-4.7$ & 90.4 & D/S \\
\hline 2 & $6200-4300$ & $0.77-2.4$ & $2.4-6.2$ & 75.6 & 75.6 \\
\hline 3 & $4300-3000$ & $1.00-3.6$ & $3.0-6.1$ & 71.0 & 61.0 \\
\hline 4 & $3000-0.0$ & $0.90-3.0$ & $2.8-5.9$ & 61.2 & 48.0 \\
\hline
\end{tabular}

Table 7: The required height of the right bank of Galal Badrah after treatment at discharge of $2200 \mathrm{~m} 3 / \mathrm{s}$.

\begin{tabular}{|c|c|c|c|}
\hline Stations & $\begin{array}{c}\text { Range of existing right } \\
\text { bank elevations, } \text { m.a.s.l. }\end{array}$ & $\begin{array}{c}\text { Real water surface } \\
\text { elevation, m.a.s.l. }\end{array}$ & $\begin{array}{c}\text { Required right bank level } \\
\text { m.a.s.l. }\end{array}$ \\
\hline $9950-6100$ & $87.80-71.70$ & $90.6-74.20$ & $91.6-76.2$ \\
\hline $6200-4700$ & $71.70-67.50$ & $74.8-72.00$ & $75.8-73.0$ \\
\hline $4300-3400$ & $67.10-64.30$ & $71.0-65.40$ & $72.0-66.4$ \\
\hline $1300-1050$ & $50.70-50.00$ & $51.8-51.50$ & $52.8-52.5$ \\
\hline
\end{tabular}

\section{Conclusions}

According to the simulation results of the one and two dimensional hydraulic models, the following conclusions can be drawn:

1. A range of velocities before protection along study reach for discharge of $2200 \mathrm{~m} 3 / \mathrm{s}$ is from 1.8 to $8.4 \mathrm{~m} / \mathrm{s}$, while it is from 1.2 to $5.2 \mathrm{~m} / \mathrm{s}$ for discharge of $1250 \mathrm{~m} 3 / \mathrm{s}$.

2. The range the longitudinal slopes of the all zones is between 390 to $500 \mathrm{~cm} / \mathrm{km}$. These slopes are the main reason of the high velocities along the river reach .

3. All parts require protections against erosion by using boulders which is suitable method than others.

4. The results of the mathematical $2 \mathrm{D}$ model showed that the range of velocity in the four protected parts for the discharge of $2200 \mathrm{~m} 3 / \mathrm{s}$ is between 0.75 and $3.6 \mathrm{~m} / \mathrm{s}$, while it is between $0.32-2.6 \mathrm{~m} / \mathrm{s}$ for discharge of $1250 \mathrm{~m} 3 / \mathrm{s}$.

5 . The percentage of reduction in the velocities after river protection for the discharges 1250 and $2200 \mathrm{~m} 3 / \mathrm{s}$ are $65.23 \%$, and $60.55 \%$, respectively .
6. The right bank of Galal Badrah river after protection require raising its height at different locations (Tables 5 and 7).

\section{Recommendations}

The following of Recommendations are suggested to any future studies.

1. Badrah Bridge piers needs special protection by using gabion till the elevation of 60 m.a.s.1., since the shear stress and velocity in this location is still high with protection by stack boulder.

2. The maximum recent acceptable discharge of Galal Badrah River is $500 \mathrm{~m} 3 / \mathrm{s}$ with few spilled meters of right bank directly $\mathrm{D} / \mathrm{S}$ the weir (at zone one) and without any damage to the city.

3. Studying the reach extending upstream of Galal Badrah weir until Iraq-Iran border to reduce the incoming sediment load into the reservoir. 


\section{References}

[1] Chow, V. T. (1959). Open channel hydraulics. McGraw-Hill Book Company, Inc; New York.

[2] Demir, V., \& Kisi, O. 2016. Flood hazard mapping by using geographic information system and hydraulic model: Mert River, Samsun, Turkey. Advances in Meteorology, 2016.

[3] Graf, W. H. (1984). Hydraulics of sediment transport. Water Resources Publication.
[4] Julien, P. Y. (2010). Erosion and sedimentation. Cambridge University

[5] U.S. Army Corps of Engineers, (2010). "Hydrologic Engi-neering Centre, River Analysis System (HECRAS Version 4.1)." (http://www.hec.usace.army.mil).

\section{تعريف مناطق الانجر اف لنهر غير مقاس بالمحاكاة: الحالة نهر كلال بدره، العراق كرييم عبد علي كريم1، حيدر عبد الامير خضير الثامري 2} kareemalialagha@gmail.com قسم الموارد المائية، جامعة بغداد، بغداد، العراق،

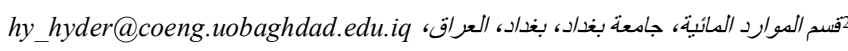

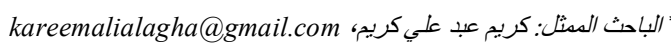
شر في: 31 آب 2019

الخلاصة - في العراق العديد من الأنهار و الجداول التي تعبر الحدود العر اقية الإيرانية، أحدها نهر كلال بدرة. يكون فيضانه خلال الفترة

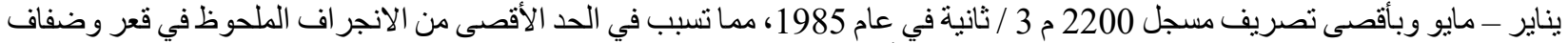

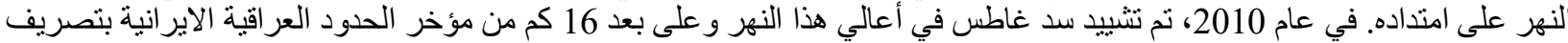

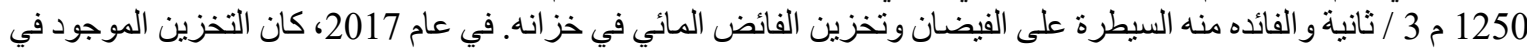

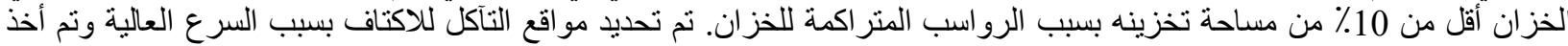

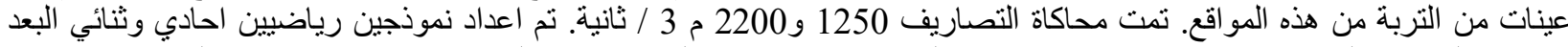

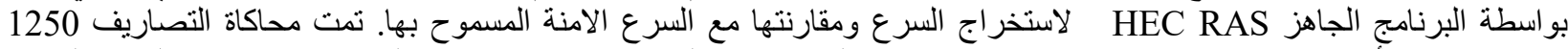

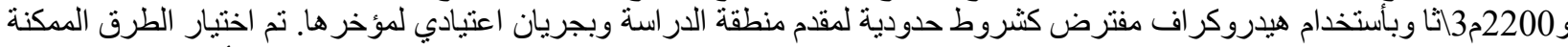

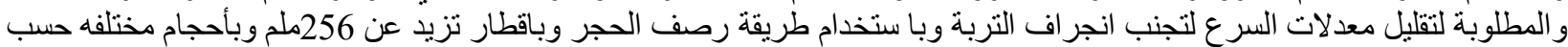

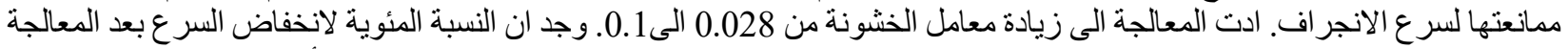

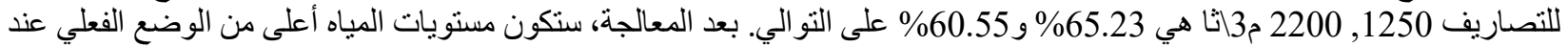

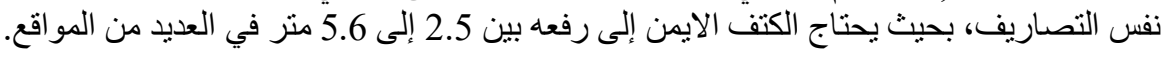
الكلمات الرئيسية - نهر كلال بدره, نموذج ثنائي الابعاد, فيضان, حماية الاكتاف. 